\title{
Designing the functional garments for people with physical disabilities or kyphosis by using computer simulation techniques
}

\author{
ANDREJA RUDOLF \\ ANDREJ CUPAR
}

DOI: $10.35530 / I T .070 .02 .1592$

ZORAN STJEPANOVIČ

\section{REZUMAT - ABSTRACT}

\section{Proiectarea îmbrăcămintei funcționale pentru persoanele cu dizabilități fizice sau cifoză prin utilizarea tehnicilor de simulare pe calculator}

\begin{abstract}
Obiectivul dublu al acestui studiu este de a documenta provocările actuale ale tehnicilor de scanare 3D și de simulare pe calculator pentru dezvoltarea de articole de îmbrăcăminte funcționale pentru persoanele cu dizabilități fizice sau cifoză posturală. Prima parte a studiului investighează problemele de sănătate ale utilizatorilor de scaune cu rotile și prezintă posibilitățile de dezvoltare a pantalonilor funcționali din perspectiva nevoilor de protecție și de sănătate. Cea de-a doua parte a studiului investighează utilitatea metodologiei nou dezvoltate pentru evaluarea suprafețelor elementare, numită CASP (Curvature, Acceleration, Symmetry, Proportionality), în procesul de proiectare a corsetului bine montat pentru utilizatorii de scaune cu rotile care suferă de afecțiunea cifoză posturală. Relațiile dintre problemele de sănătate, pozițiile corpului uman, cifoza, scanarea $3 D$, evaluarea CASP și articolele de îmbrăcăminte tratate au fost luate în considerare în procesul de prototipare. Rezultatele obținute în ceea ce privește pantalonii funcționali pentru utilizatorii de scaune cu rotile și corsetul bine montat pentru un corp cu cifoză sunt valoroase și pentru o populație mai largă a celor care sunt forțați să stea în picioare în timpul zilei și care se confruntă cu probleme de sănătate similare, cum ar fi persoanele care suferă de paraplegie sau cele care sunt afectate de cifoză.
\end{abstract}

Cuvinte-cheie: îmbrăcăminte funcțională, dizabilitate fizică, afecțiuni posturale, scanare 3D, metodologie CASP, tehnici de simulare pe calculator

\section{Designing the functional garments for people with physical disabilities or kyphosis by using computer simulation techniques}

The two-fold purpose of this study is to document the current challenges of the $3 D$ scanning and computer simulation techniques in developing functional garments for people with physical disabilities or postural disorder kyphosis. The first part of the study investigates the health problems of the wheelchair users and presents the possibilities of developing functional pants from the perspective of protection and health needs. The second part of the study investigates the usefulness of the newly developed methodology for elementary surfaces evaluation, named CASP (Curvature, Acceleration, Symmetry, Proportionality), in the process of designing the well-fitted bodice for wheelchair users suffering from the postural disorder kyphosis. The relationships between the health problems, human body postures, kyphosis, $3 D$ scanning, CASP evaluation and treated garments were considered in the prototyping process. The obtained research results regarding the functional pants for wheelchair users and the well-fitted bodice for a kyphosis body are valuable also for a wider population of those who are forced to a sitting posture during a day and are confronted with similar health problems as paraplegics or are affected by the kyphosis.

Keywords: functional garments, physical disability, postural disorders, 3D scanning, CASP methodology, computer simulation techniques

\section{INTRODUCTION}

The classification of functional garments by Gupta [1] varies due to the specifics of each functionality, requirements of the textile materials and, consequently, the production technologies. The design and development of functional garments, such as protective, medical, sport, cosmetic vanity, cross-functional and special needs garments is based on (a) the choice of textile materials, as defined by the social, psychological or physiological requirements of the user, (b) the choice of technologies as defined by the desired functionality and (c) the ergonomic considerations, assembly methods, sizing and fit. Garments for people with special needs represent a group of functional garments intended to improve the quality of life of the human population whose body shape, size, mobility or dexterity differ significantly from nondisabled people [1-2].

The work by Meinander and Varheenmaa highlights that the quality of life for the disabled people can be, in many cases, improved substantially by a better choice of good-looking garments, which are also functional at the same time [3]. Some research works had highlighted the difficulties of disabled users in finding suitable garments and the social importance of their appearances [4-8]. They indicated the importance of garments' designs and the individual adoptions of garments according to the disabled users' impairment, functional needs and individual body postures and measurements. In the research by Chang et al. it was found out that the garments form and function, 
self-expression and social identity are the basic requests for garment selections and usages [9].

Virtual cloth and clothing simulation received significant attention in the past decade. Today, advanced computer simulation techniques and garments virtual prototyping are indispensable for the development of garments and their fitting on the 3D body models within a virtual environment, as well as real-time virtual clothes try-on [10-13]. It was discovered that virtual prototyping and garments fitting represent a problem for the standard [14,15] and non-standard body shapes [16-17]. Therefore, in the last two studies, scanning of the human bodies had been involved to enhance the reliability of the garments' virtual development. In addition, an approach into the virtual prototyping of individually adapted garments for paraplegics was investigated [7]. It was based on the 3D scans of fully mobile individuals in a sitting posture to avoid unnecessary burdening of paraplegics in the first stage of the research. In continuation, the $3 \mathrm{D}$ scans of the fully mobile and immobile persons using a wheelchair were carried out and a comparative analysis of the scanned 3D bodies' virtual measurements and manual measurements was performed for fully mobile and immobile persons to found if the poor body balance of the immobile persons affects the accuracy of 3D body models [8]. In this research statistical results indicated that the mobility of a person did not affect the accuracy of the virtual measurements. In addition, the virtual simulation technology showed that ergonomic garments could be developed without unnecessary burdening of the immobile persons with the usual fitting trials of the real garments [8].

The research works into the virtual prototyping of the adapted garments for people with disabilities are concentrating also to development of a generalized adaptive 3D body model, the posture of which could be adapted to different postures, with the aim of designing the universal parametric 3D body model [18-19]. On the other hand, research works focus on (1) the impact of body posture and shape on the garment fit and (2) designing process of customized garments for people with postural disorders. In the research by Petrak et al. [20] the relationships between targeted body measurements and their impact on modifications of pattern segments were investigated for defining mathematical expressions, according to which the garment pattern design changes its dimensions. In the works by Stjepanovič et al. and Rudolf et al. the new CASP methodology for design and virtual prototyping of garments, adapted to body postures of people with scoliosis was investigated [21-23]. The CASP abbreviation, which is derived from words Curvature, Acceleration, Symmetry and Proportionality, can be used for geometrical surfaces' analysis and their evaluation. An early stage of this newly developed analysis methodology has already been proposed in a research by Cupar et al. [24]. In the research works by Hong et al. the method for generating of the two-dimensional (2D) basic pattern designs for physically disabled people with scoliosis was presented by using the three-dimensional (3D) virtual technology [25-27]. In this two-fold study, we focused on designing of functional garments for people with physical disabilities and postural disorder kyphosis by using the 3D scanning, CASP methodology and computer simulation techniques. Based on the data collected from fifty-eight in depth interviews, conducted with adult wheelchair users at the national level, related to their health problems and garments, the 3D scanning and computer simulation approach was studied for designing of the functional garments for health protection of the wheelchair users. In the second part, the approach for designing of well-fitted garments for people suffering from kyphosis was studied by using the CASP evaluation of the roundback and incorporation of the obtained values into the process of virtual prototyping.

\section{STUDY REGARDING THE HEALTH PROBLEMS OF WHEELCHAIR USERS AND DESIGNING OF FUNCTIONAL GARMENTS}

Interviewing of the wheelchair users regarding the health problems

For a detailed knowledge of the paraplegic wheelchair users, a questionnaire was designed to receive objective and subjective data regarding their accompanying health problems related to the garments. Therefore, the questionnaire had closed and open answers. Interviewing was conducted in Slovenia among 58 adult respondents, both male $(65.5 \%)$ and female (34.5\%) paraplegics who use a wheelchair from 1 to 46 years. The age of the respondents ranged between 18 and 67 years [28].

\section{The survey of the health problems}

The survey showed that paraplegic wheelchair users were mostly faced with incontinence $(66.7 \%)$, then with infection and inflammation of the urinary tract $(50.0 \%)$, frequent colds $(33.3 \%)$, while a smaller number having pressure sores $(14.6 \%)$, skin irritations and inflammations $(12.5 \%)$. The hand pains $(50.0 \%)$ and leg cramps $(41.7 \%)$ were common health problems of paraplegics.

The open answers in questionnaire revealed that irritations and inflammations of the skin and, consequently, the resulting wounds arose in particular in the areas of the crotch, between the thighs and in contacts of the body with the wheelchair. In addition, the presence of moisture in the garment or between the garment and wheelchair may even lead to infections. They sweat the most under the buttock, lumbar and between the thighs; the moisture may increase friction and produce blisters and ulcerations. The unpleasant odour of the underpants arises due to urine loss and transfer of the odour to the pants. Therefore, they need to wash pants more often than usual. Because of the frequent skin allergies and dermatitis, they prefer to wear clothes made of natural and breathable textile materials. In general, paraplegics also suffer from the spinal pain, problems with 
veins and swelling legs, and postural disorders (scoliosis, lordosis, kyphosis) because of muscular imbalance and poor body balance.

The questionnaire contained also questions about buying garments and preferred characteristics of garments. The data clearly showed that the vast majority of wheelchair users buy clothes in normal stores $(96.6 \%)$. Only $10.3 \%$ use made-to-measure clothing, whilst the percentage of those who buy clothes in specialized trade shops or made to measure was very small $(1.7 \%)$. The open questions revealed that there was no offer of specialized garments for paraplegics on the domestic market, whilst online shops offered specialized clothes that are adapted to a wider group of people with disabilities. Concerning the custom-made clothes, they are consumers with highly individualized needs and had strong desire regarding the specialized fashion studios producing custom-made garments. The most desired garment characteristic was to be comfortable (87.8\%), functional $(79.3 \%)$, aesthetic $(67.2 \%)$ and fashionable $(24.1 \%)$. The open answers revealed that there are no adequate size numbers and garments pattern designs for them in regular stores, therefore, it affects their poor wearing comfort in a sitting posture, unpleasant appearance, and impedes their motion with the wheelchair. The durability of textile materials and functional demands regarding the (un)dressing, using toilet, positions of pockets and seams, handling with the urine bag, etc. were most highlighted problems.

Based on the questionnaire survey it could be concluded that paraplegics do not fit into current garments size systems and, therefore, garments in regular stores on the market. This research revealed that adapted garments should be designed according to the needs and wishes of the individual users regarding the ergonomic and functional garment pattern design that do not cause additional health problems, but rather act as a prevention or curative manner for their accompanying health problem(s) and having an aesthetic appearance. Namely, it was recognized that the urine incontinence and sweating can cause the skin in the buttocks and perineal area to be chronically moist, and contamination of the potential open wounds with urine and sweat interferes with wound healing. In addition, there is a high risk of developing a pressure sore (ischial or trochanter) and postural disorder kyphosis due to daily sitting in a wheelchair. These findings have shown us the following two directions for further studies:

(a) Development of antimicrobial and antioxidant activity of the viscose textile material that can act as a prevention and curative manner regarding the extended incontinence and sweating [29].

(b) Development of individually adapted functional garments in terms of individuals' health problems by using the computer simulation techniques and CASP methodology.

\section{DEVELOPMENT METHODOLOGY FOR} INDIVIDUALLY ADAPTED GARMENTS

\section{Designing of functional pants for wheelchair} users by using computer simulation techniques

The purpose of this part of the research was to explore the meaning of the 3D scanning and virtual prototyping of functional garments regarding the individual need of the paraplegic wheelchair user. The usefulness and effectiveness of the 3D scanning and virtual prototyping of the garments for a sitting posture were studied in sources [7-8, 28]. In the latest studies, the special chair for scanning was developed. The chair is assembled with screw connections, which allows flawless transportation to different scanning locations. This chair has a significant importance for later processing and modeling of the 3D scanned bodies in order to get as much as possible realistic body measurements. Namely, a commercial wheelchair has too much supports, which cover the body. Therefore, it is not possible to fully digitize the body. A synergistic effect of the new technologies, i.e. 3D body scanning in a sitting posture by using the optical hand-held scanner Artec Eva 3D and virtual prototyping, during the development process of the ergonomic garments showed a great potential for their use and radical changes in the custom-made garments' production for wheelchair users. It has been proven that ergonomic garments with functional solutions regarding the daily activities of wheelchair users can be developed without unnecessary burdening of them with usual fitting trials of the real garments.

In this study recognized accompanying health problems of the paraplegic wheelchair users, such as incontinence, pressure sores and sweating due to sitting in a wheelchair, relate primarily to one particular garment item, the pants. Therefore, the conceptual prototypes of the pants pattern designs were developed with respect to different health problems of paraplegics by using the virtual prototyping with OptiTex 3D software program on the scanned 3D body models of the paraplegic wheelchair users. The pants' basic pattern designs, ergonomically adapted to a sitting posture, were constructed according to the procedure described in a source [7].

In a case of incontinence or sweating the chronically moist of the skin, especially, the crotch area, between the thighs and contacts of the body with a wheelchair were found to be the major problem for potential skin irritations and inflammations or even wounds. Therefore, by using the antimicrobial and antioxidative textile materials (AATM) in these specific locations in the pants, the prevention against potential health problems can be achieved with development of well-fitted functional pants. A digitized 3D body model permits to simulate person's morphological shape and extract the main features of a body shape and body measurements. Using the virtual prototyping, 2D-to-3D approach enables to validate different design ideas within a very short time on the 3D human body. When integrating the AATM in certain 
locations of the pants attention must be paid to the position of the seams. The seams shall not be in places of the contact of the body with a wheelchair, otherwise they can cause additional health problems. The virtual environment enables inspection of the shape and features of the human body, as well as estimation of the garment fit to the $3 \mathrm{D}$ body model. This allows us to develop accurate and reliable garment pattern designs for even the most demanding population. An example of the pants with integrated AATM that acts as a protection regarding the chronically skin moistening is shown in figure 1 . The advantage of this type of the pants prototype is that they are ergonomically adapted to the individual person's body shape, its physical dimensions and sitting posture with added functional characteristic for the health protection.

The pants pattern design for a wheelchair user with a pressure sore on the hips as a result of constant pressure of the body to a wheelchair is shown in figure 2. The 3D scanning of human bodies also enables the exact location of the body feature points and wounds, respectively. Therefore, developed ergonomic pants with integrated functional textile material AATM exact into the place of the wound, which was previously medically treated, acts as a curative.

Overall, this study shows a new step towards the social responsibility and efficient approach to responsible development of functional garments not only for wheelchair users, but also for elderly and persons who are forced to a sitting posture during the day, and could not find appropriate clothes in regular stores.

\section{Designing of well-fitted bodice for people suffering from kyphosis by using CASP methodology}

In this study, we have also recognized additional accompanying health problems of the paraplegic wheelchair users, such as the postural disorder kyphosis due to daily sitting in a wheelchair.

Kyphosis is caused by a spinal disorder in which an excessive outward curve of the spine results in an abnormal rounding of the upper back, known as the "roundback", while in the case of a severe curve is known as the "hunchback." Kyphosis can occur at any age; besides the wheelchair users it can affect also children and more common elderly or office and other workers in a forced outright posture [30].

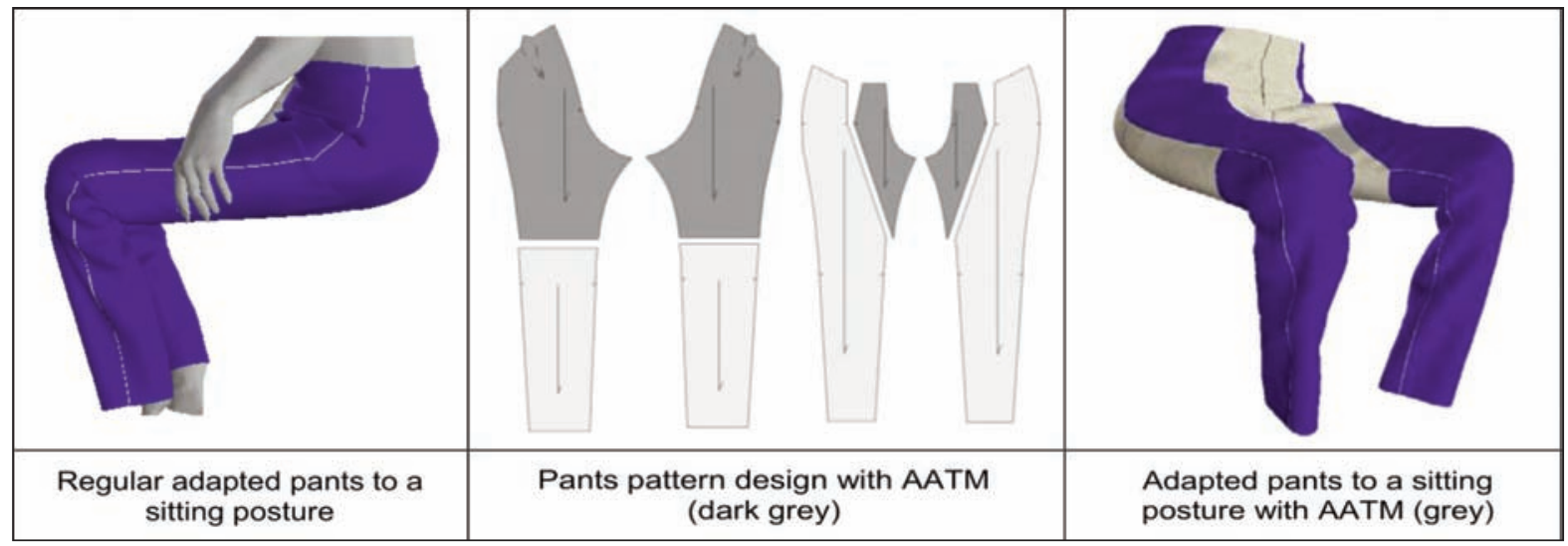

Fig. 1. Pants with integrated antimicrobial and antioxidative textile material (AATM) that acts as a protection regarding the chronically skin moistening

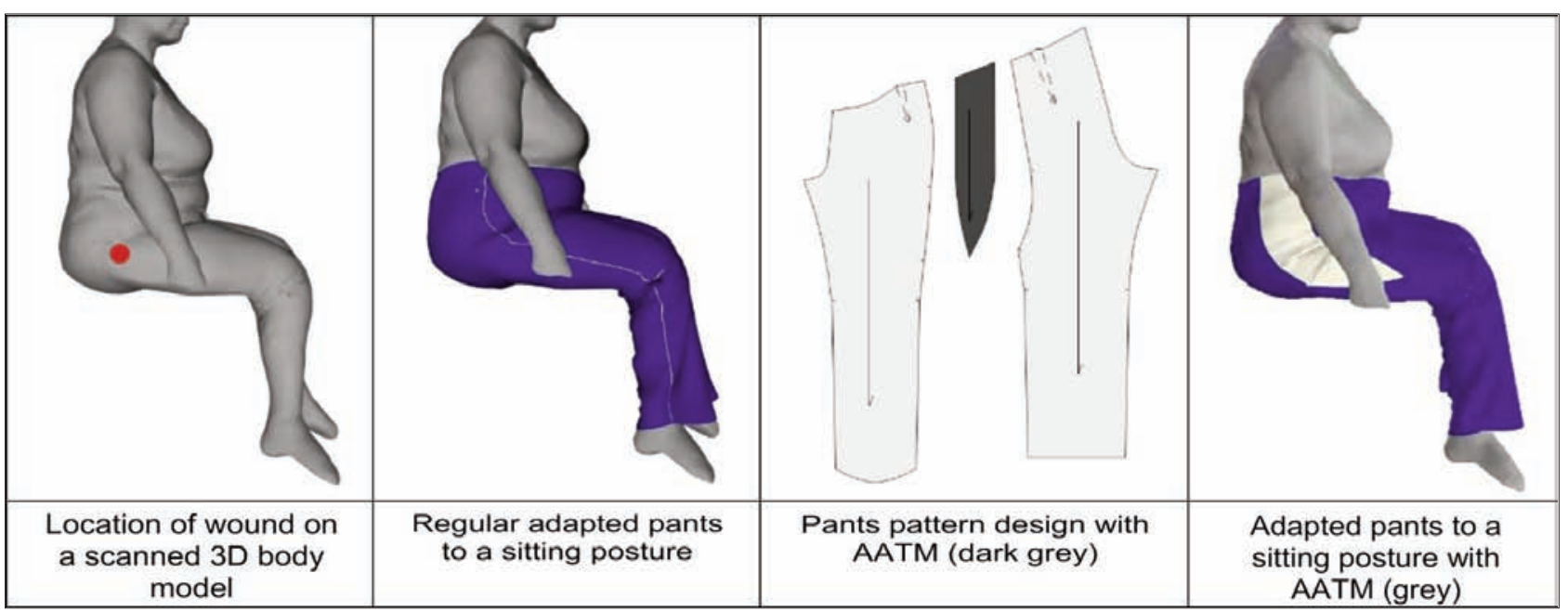

Fig. 2. Pants with integrated AATM for curative purpose regarding the pressure sore on hips 
When persons with kyphosis wear for example classic dress or jackets, these garments do not fit well the body due to the roundback. Visible tensions and/or wrinkling, shortening of clothes on the back part and prolongation on the front part etc. arises, which additionally accentuates this postural disorder. The purpose of clothing is not to deteriorate the appearance of a person, but to improve it with appropriate clothing. The way we feel about our bodies can affect all aspects of our daily life. If we are wearing clothes that fit well and help us feel comfortable, this inevitably helps to boost our confidence. Therefore, this part of the study concentrates on use of the CASP methodology in designing process of the ergonomically adapted bodice for people suffering from kyphosis with the aim to improve the bodice fitting, wearing comfort and appearance of the person.

Methodology CASP (Curvature, Acceleration, Symmetry, Proportionality) is used for surfaces' analysis. It was originally developed as a method for classification of perceptual surfaces and for analyzing digital geometry [20, 24, 31]. Methodology of surface evaluation was developed to establish the meta-language in design communication, which was perceived as necessary part of styling. The first step was analysis of existing geometry and the second a synthesis of newly created geometry considering desired property. Four properties, which characterize the surfaces, are similar to characterization of colours in colour space. In studies regarding the use of the CASP methodology, it was found out that it is suitable for the purpose of analysis of the deformed areas of a human's body and offers an important support during the construction of adapted garments for people with scoliosis [20] and kyphosis [22].

For the purpose of this study, synthetic 3D body models using Makehuman and Blender 3D software [32, 33] were prepared with a normal spine ( $0 \mathrm{deg}$ ) and slightly curved (15 deg), curved (20 deg) and strongly curved (25 deg) spines in the area of the roundback, found in the case of kyphosis. The 3D body models were analyzed using the CASP methodology in the roundback area and the CASP analysis was carried out using the Grasshopper and Rhinoceros software [34-35]. The observation plane was projected on an imported 3D body mesh model and on the

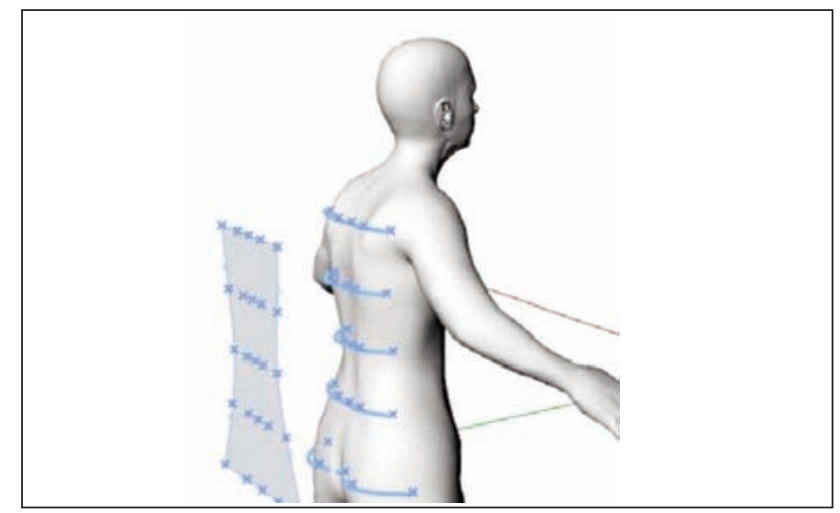

Fig. 3. Analysis of the roundback area using the CASP methodology roundback, respectively (figure 3 ). In addition, calculations of the CASP parameters were carried out by Grasshoppers $n x n$ procedure. Values for CASP were obtained as a numerical result.

The 3D body models were imported into the OptiTex PDS/3D system and virtual measurements of the back lengths $\left(\mathrm{BL}-\right.$ from the $7^{\text {th }}$ cervical vertebra to the waist line) were performed according to the standard ISO 8559 [36].

The results showed that CASP values, especially $C$ and $A$, increase with an increase in the spine deformation, whilst the parameters $S$ and $P$ are independent regarding the spine deformation. The $\mathrm{C}$ of the normal body was 1.69 , slightly curved 2.56 , curved 3.13 and it increased for the strongly curved spine up to 3.26 . The $A$ of the normal body was -3.73 and it decreased for the slightly curved spine to -14.97 and for the curved spine to -55.79 , whilst it was for the strongly curved spine -127.35 . The back length (BL) also increased with an increase in the spine deformation. It was for the normal spine $33.19 \mathrm{~cm}$, for the slightly curved spine $34.95 \mathrm{~cm}$, for the curved spine $36.14 \mathrm{~cm}$ and for the strongly curved spine $36.31 \mathrm{~cm}$ [22].

In addition, the differences (D) between the normal spine and deformed spines for the back length (DBL) and CASP parameters for the Curvature difference (DC) and the acceleration difference (DA) were calculated, as well as quotients between DC and DBL, and between DA and DBL, table 1 .

Table 1

\begin{tabular}{|c|c|c|c|c|}
\hline \multirow[b]{2}{*}{ Parameter } & \multicolumn{4}{|c|}{ Spine } \\
\hline & normal & $\begin{array}{l}\text { slightly } \\
\text { curved }\end{array}$ & curved & $\begin{array}{c}\text { strongly } \\
\text { curved }\end{array}$ \\
\hline C & I & 0,87 & 1,44 & 1,57 \\
\hline A & I & 11,24 & 52,06 & 123,62 \\
\hline $\mathrm{BL}(\mathrm{cm})$ & I & 1,76 & 2,95 & 3,12 \\
\hline $\mathrm{C} / \mathrm{DBL}\left(\mathrm{cm}^{-1}\right)$ & I & 0,49 & 0,49 & 0,50 \\
\hline $\mathrm{A} / \mathrm{DBL}\left(\mathrm{cm}^{-1}\right)$ & 1 & 6,39 & 17,65 & 39,62 \\
\hline
\end{tabular}

The results show that the ratio DC/DBL is almost the same for all spine curvatures and equals 0.5 (table 1). Based on this part of the research it could be concluded that the back length difference is two times higher than the curvature difference. This means that the CASP parameter for the curvature difference (DC) may be possible to be included directly in the process of reconstruction of the garment pattern design to a specific body shape, with the assumption that the value of the parameter DC is used in centimeters. The reconstruction of garment pattern design is usually carried out by observation of the body shape and measuring of body dimensions, which is a lengthy process in terms of manufacturing and garments fitting. Therefore, we assume that with CASP analysis it is possible to significantly shorten 


slightly curved SPINE strongly curved

Fig. 4. The virtual fitting of the bodice basic pattern design to a normal 3D body model

the process of reconstruction of the garment pattern design.

The bodice basic pattern design was constructed according to the normal (symmetric) synthetic female body by using rules of the construction system $M$. Müller\&Sohn [37] and OptiTex CAD/PDS system [38] (figure 4). The results regarding the virtual fitting of the bodice basic pattern design to a normal and kyphosis 3D body models show that with an increase in the spine curvature the bodice front lengths increases and the bodice back lengths decreases. Therefore, the waistline is not horizontal, and inappropriate fitting and tension in the roundback appeared, which consequently causes bad wearing comfort and appearance of the wearer in the bodice. This was confirmed also by the average Tensions $X Y$ of the garments, which were determined with Optitex software function. An increase in the average Tension $X Y$ with an increase in the spine curvature can be seen, which also indicates an increase of the areas of the red, yellow and green colours.

The reconstruction of the bodice basic pattern design was carried out according to calculated values for the curvature difference (DC) for the slightly curved, curved and strongly curved kyphosis spine. The virtual fittings of the reconstructed bodice basic pattern design were performed on the 3D kyphosis body models (figure 5). During the reconstruction, the front middles were shortened for the double value of DC (in $\mathrm{cm}$ ) and the back middles were extended for the double value of DC (in $\mathrm{cm}$ ), whilst the back darts were extended and raised for the DC (in $\mathrm{cm}$ ). Based on a comparison of the bodice pattern design for the normal posture and the reconstructed bodice pattern design for the strongly curved kyphosis spine, the reconstruction procedure of the bodice can be seen in figure 6 . In addition, the analysis of the bodice pattern pieces' surfaces was carried out, table 2 .

The results regarding the virtual fitting of the reconstructed bodice pattern designs to kyphosis 3D body models show a horizontal bottom edge of all simulated bodices. This can be seen on the side views and bodices pattern designs' meshes for the back views (figure 5). In addition, a decrease in areas of the red, yellow and green colours appeared, as well as a decrease in the average Tension $\mathrm{XY}$ in the material, 


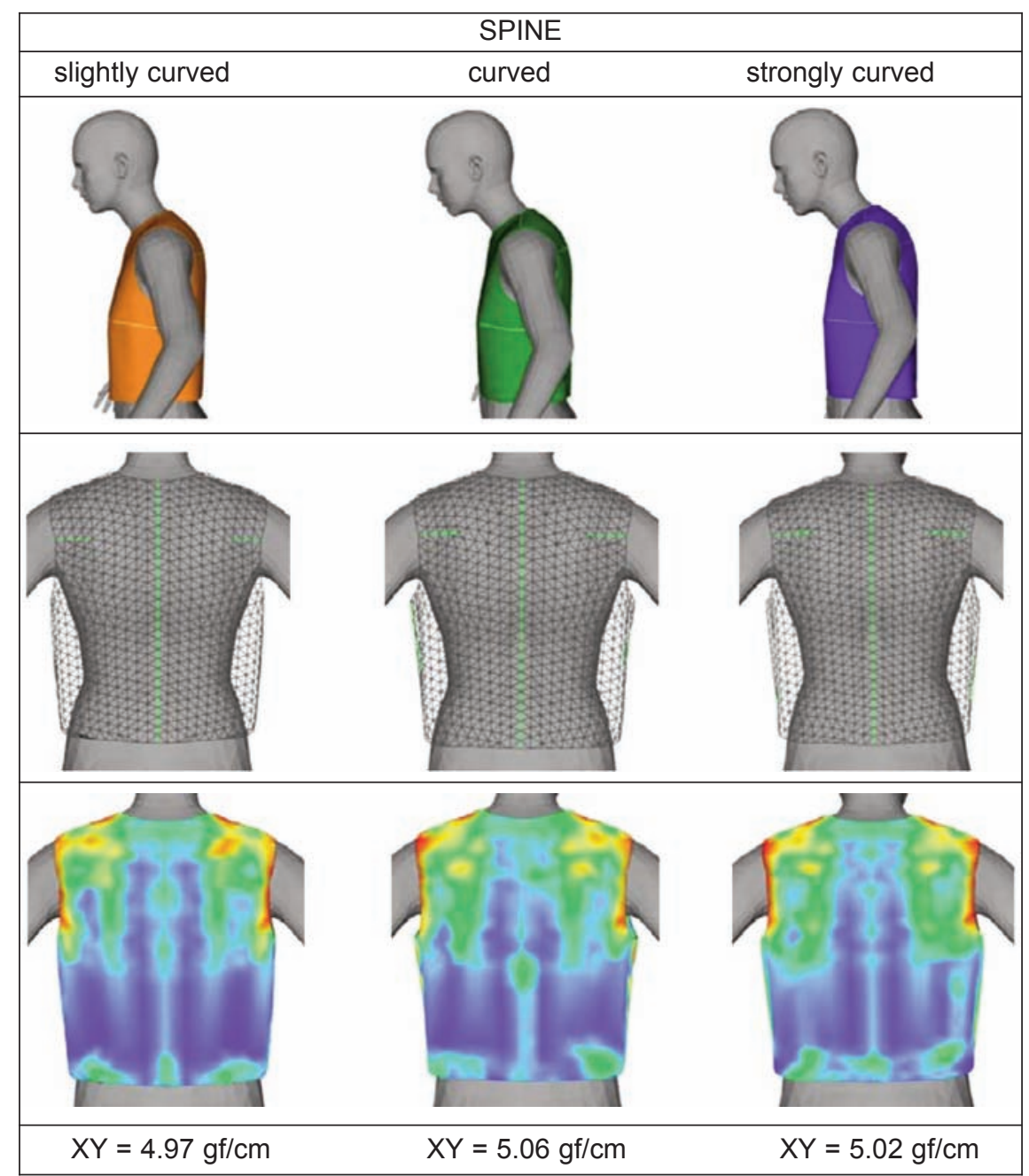

Fig. 5. The virtual fitting of the reconstructed bodice basic pattern design to deformed 3D body models regarding the kyphosis spine
(DC) for curved spines, respectively, improved bodice fitting and at the same time higher wearing comfort and bodice appearance were achieved in terms of garment pattern design.

With the aim to confirm the changes of the basic pattern pieces the reconstructed basic pattern pieces were evaluated with the surface areas, and the differences between the surface areas for the normal and kyphosis bodies $\left(D_{N-K}\right)$ were calculated, as well as their percentages (table 2). As expected, the surface areas of the front pattern pieces decreased with increased curvature of the spine from $31.6 \mathrm{~cm}^{2}$ for a slightly curved spine to $46.58 \mathrm{~cm}^{2}$ for the strongly curved spine. The surface areas of the back pattern pieces increased with an increase in the spine curvature from $16.84 \mathrm{~cm}^{2}$ for a slightly curved spine to $37.35 \mathrm{~cm}^{2}$ for the strongly curved spine. The surface areas of the front and back pattern pieces were not changed equally with an increase of the spine curvature. This is attributed to a greater

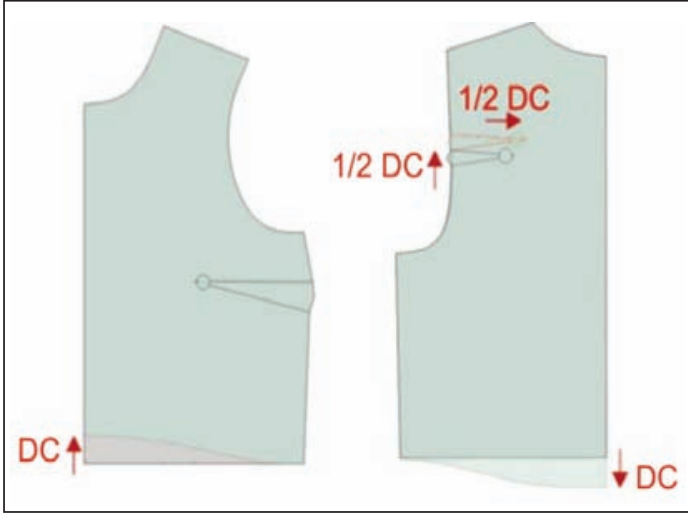

Fig. 6. Comparison of the bodice pattern design for the normal spine curvature and reconstructed bodice pattern design for strongly curved spine

\begin{tabular}{|c|c|c|c|c|}
\hline \multicolumn{5}{|c|}{ THE SURFACES OF THE BODICE PATTERN PIECES } \\
\hline \multirow{2}{*}{$\begin{array}{l}\text { Bodice pattern pieces } \\
\text { surface areas }\end{array}$} & \multicolumn{4}{|c|}{ Spine } \\
\hline & normal & $\begin{array}{l}\text { slightly } \\
\text { curved }\end{array}$ & curved & \begin{tabular}{|c|} 
strongly \\
curved
\end{tabular} \\
\hline $\begin{array}{ll}\text { Front } & \left(\mathrm{cm}^{2}\right) \\
\text { Difference }\left(D_{N-K}\right) & \left(\mathrm{cm}^{2}\right)^{*} \\
\text { Percentage }\left(D_{N-K}\right) & (\%)^{* *}\end{array}$ & 857.33 & $\begin{array}{c}825.73 \\
31.60 \\
3.69\end{array}$ & $\begin{array}{c}812.15 \\
45.18 \\
5.27\end{array}$ & $\begin{array}{c}810.75 \\
46.58 \\
5.43\end{array}$ \\
\hline $\begin{array}{ll}\text { Back } & \left(\mathrm{cm}^{2}\right) \\
\text { Difference }\left(D_{N-K}\right) & \left(\mathrm{cm}^{2}\right) \\
\text { Percentage }\left(D_{N-K}\right) & (\%)\end{array}$ & 780.44 & $\begin{array}{c}797.28 \\
16.84 \\
2.16\end{array}$ & $\begin{array}{c}808.08 \\
27.64 \\
3.54\end{array}$ & $\begin{array}{c}817.79 \\
37.35 \\
4.79\end{array}$ \\
\hline
\end{tabular}

${ }^{*}$ Absolute differences between the surface for the normal and kyphosis bodies in $\mathrm{cm}^{2}$.

** Percentages of differences between the surface for the normal and kyphosis bodies in \%. respectively. It is almost the same for all three adapted garments and similar to the garment for normal spine curvature after reconstruction of the bodice, which consequently means greater comfort of the body in the reconstructed bodices. Based on these findings it can be concluded that with a reconstruction of the bodice by using the measured and calculated CASP values and the curvature differences surface area of the front bodice pattern peace compared to the back pattern piece due to women's breasts. Therefore, it could be concluded that for men having kyphosis the reconstruction process should be different and further explored.

Based on the results of this part of the research it can be concluded that the CASP methodology proved to 
be adequate for defining the appropriate bodice pattern design for female persons with a curved spine. However, it is necessary to carry out additional research work in the future on a larger number of diverse curvatures of the kyphosis spine with real female persons, to confirm the findings of this research.

\section{CONCLUSIONS}

Advances in complex medicine rehabilitation allow people with spinal cord injuries to return to a wider social and working environment. The resulting disabilities often lead to special functional requirements regarding the garments. Therefore, the quality of life for wheelchair users and disabled persons suffering from postural disorders could be improved significantly by offering a better choice of aesthetic and well-fitted functional garments.

In this research, the main aim was to face the most common accompanying health problems of the wheelchair users and those persons suffering from kyphosis and to study the possibilities for integration of the 3D scanning, CASP methodology and computer simulation techniques in the designing process of functional garments adapted to individuals' needs. In this study, we have researched the pants and bodice for females.

Research into the accompanying health problems of paraplegics showed that these are primarily infections and inflammations of the urinary tract, incontinence, skin irritations and inflammations and skin wounds. It was discovered that the perineal area, between the thighs and contacts of the body with a wheelchair represent critical parts, which are characterized in terms of garments, mainly for the pants. In addition, paraplegics also suffer from postural disorders, mostly from scoliosis and kyphosis, which sets specific requirements related to the garments for the upper part of the body. The research showed that paraplegics need individually adapted functional garments with regard to their medical condition and their accompanying health problems that act in a prevention or curative manner and offer wearing comfort and aesthetical appearance.

This study showed that individualized functional garments for people with physical disabilities and postural disorders could be successfully developed by using the 3D scanning, CASP methodology and computer simulation techniques. Moreover, the results of this research regarding the bodice pattern design by using CASP methodology are valuable not only for wheelchair users having kyphosis, but also for a wider population suffering from kyphosis.

Today, manufacturers of diverse products dedicate the production process increasingly towards the personalised products. Therefore, production of textile products presented in this research by using the computer simulation approach could be a successful solution for persons suffering from postural disorder kyphosis, paraplegics and other wheelchair users and those elderly persons who are forced to a sitting posture during the day having similar health problems and could not find appropriate garments in regular stores.

\section{ACKNOWLEDGEMENT}

The authors would like to express their gratitude to the Paraplegic association Podravje, Slovenia and their members for valuable contribution to the project.

\section{FUNDING}

The authors would like to express their thanks to the Slovenian Ministry of Education, Science and Sport and European Union through the European Social Fund (Contract number: 11047-23/2014), EC Programme Erasmus+, project TexMatrix (Contract number: 2016-1R001-KA202-024498), as well as to the Slovenian Research Agency (Research Programme P2-0123: Clothing Science, Comfort and Textile Materials), which funding enabled the realisation of a part of this study.

\section{BIBLIOGRAPHY}

[1] Gupta D. Functional clothing - Definition and classification, In: Indian Journal of Fibre \& Textile Research, 2011; vol. 36, pp. 321-326.

[2] Curteza A., Cretu V., Macovei L., Poboroniuc M. Designing Functional Clothes for Persons with Locomotor Disabilities. In: Autex Research Journal, 2014. vol. 14, no. 4, pp. 281-289.

[3] Meinander H., Varheenmaa M. Clothing and textiles for disabled and elderly people, In: VTT Research Notes 2143", pp. 7-28, Julkaisija - Utgivare - Publisher, Otamedia Oy, 2002.

[4] Chang W.M., Zhao Y.X., Guo R.P., Wang Q., Gu X.D. Design and Study of Clothing Structure for People with Limb Disabilities. In: Journal of Fiber Bioengineering and Informatics, 2009, vol. 2, no. 2, pp. 61-66.

[5] Thoren M. Systems approach to clothing for disabled users. Why is it difficult for disabled users to find suitable clothing. In: Applied Ergonomics, 1996, vol. 27, no. 6, pp. 389-396.

[6] Lamb J.M. Disability and the social importance of appearance. In: Clothing and Textiles Research Journal, 2001, vol. 19, no. 3, pp. 134-143.

[7] Rudolf A., Cupar A., Kozar T., Stjepanović Z. Study regarding the virtual prototyping of garments for paraplegics. In: Fibers and Polymers, 2015, vol. 16, no. 5, pp. 1177-1192. 
[8] Rudolf A., Görlichová L., Kirbiš J., Repnik J., Salobir A., Selimović I., Drstvenšek I. New technologies in the development of ergonomic garments for wheelchair users in a virtual environment, In: Industria Textila, 2017, vol. 68, no. 2, pp. 83-94.

[9] Chang H.J.J., Hodges N., Yurchisin J. Consumers with disabilities: A qualitative exploration of clothing selection and use among female college students. In: Clothing and Textiles Research Journal, 2014, vol. 32, no. 1, pp. 34-48.

[10] Aileni R.M., Ciocoiu M., Fărîmă D., Modeling and 3D simulation of the garment product. In: Industria Textila, 2011, vol. 62, no. 3, pp. 141-145.

[11] Dayik M., Yuksel H., Colak O. Real-time virtual clothes try-on system, In: Industria Textila, 2016, vol., no. 67, pp. 396-401.

[12] Aksoy C., Dayik M. Three dimensional online virtual apparel internet page application, In: Industria Textila, 2016, vol. 67, no. 4, pp. 256-259.

[13] Dāboliņa I., Viļumsone A., Dāboliņš J., Strazdiene E., Lapkovska E. Usability of 3D anthropometrical data in CAD/CAM patterns, In: International Journal of Fashion Design, Technology and Education, 2018, vol. 11., no. 1, pp. 41-52.

[14] Ancutiene K. Comparative analysis of real and virtual garment fit, In: Industria Textila, 2014, vol. 65, no. 3, pp. 158-165.

[15] Ancutiene K., Strazdiene E., Lekeckas K. Quality evaluation of the appearance of virtual close-fitting woven garments, In: The Journal of the Textile Institute, 2014, vol. 105, no. 3, pp. 337-347.

[16] Stjepanovič Z., Rudolf A., Jevšnik S., Cupar A., Pogačar V., Geršak J. 3D virtual prototyping of a ski jumpsuit based on a reconstructed body scan model. In: Buletinul Institutului Politehnic din laşi. Secţia Textile, 2011, Pielärie 1, pp. 17-30.

[17] Pilar T., Stjepanovič Z., Jevšnik S. Evaluation of fitting virtual 3D skirt prototypes to body, In: Tekstilec, 2013, vol. 56, no. 1, pp. 47-62.

[18] Kozar T., Rudolf A., Cupar A., Jevšnik S., Stjepanovič Z. Designing an adaptive 3D body model suitable for people with limited body abilities, In: Journal of textile science \& engineering, 2014, vol. 4, no. 5, pp. 1-13.

[19] Kozar T., Stjepanovič Z., Jevšnik S., Rudolf A. Impact of textile materials' parameters on behaviour/tension loads of virtual garments using sitting posture body models, In: Vlákna a textile, 2015, vol. 22, no. 1, pp. 21-26.

[20] Petrak S., Mahnić M., Rogale D. Impact of male body posture and shape on design and garment fit, In: Fibres \& Textiles in Eastern Europe, 2015, vol. 23, no. 6, pp. 150-158.

[21] Stjepanovič Z., Cupar A., Jevšnik S., Kocjan-Stjepanovič T., Rudolf A. Construction of adapted garments for people with scoliosis using virtual prototyping and CASP method. In: Industria textile, 2016, vol. 67, no. 2, pp. 141-148.

[22] Stjepanović Z., Cupar A., Jevšnik S., Kocjan-Stjepanovič T., Rudolf A. Applying CASP method for construction of adapted garments for people with scoliosis. V: Ghituleasa, Carmen (ur.). 7th TEXTEH International conference proceedings, Bucharest, Romania, October 22-23, 2015, (Tex Teh, ISSN 2068-9101, Vol. 7). Bucharest (Romania): Certex Publishing House, 2015, pp. 276-285.

[23] Rudolf A., Stjepanovič Z., Jevšnik S., Cupar A. Research on the applicability of CASP methodology for nonstandard body shapes' garment pattern design. In: Proceedings of 16th World Textile Conference AUTEX 2016, 8-10 June 2016, Ljubljana, Slovenia. Ljubljana: Faculty of Natural Sciences and Engineering, Department of Textiles, Graphic Arts and Design, 2016, pp. 1-7.

[24] Cupar A., Kaljun J., Pogačar V., Stjepanovič Z. Methodology framework for surface shape evaluation. In: Proceedings of the International Conference on Mechanical Engineering (ME 2015), pp. 58-65, Vienna, Austria, 2015.

[25] Hong Y., Zeng X., Bruniaux P., Liu K. Interactive virtual try-on based three-dimensional garment block design for disabled people of scoliosis type, In: Textile Research Journal, 2016, First Published June 3, pp. 1261-1274.

[26] Hong Y., Bruniaux P., Zeng X., Liu K., Chen Y., Dong M. Virtual reality-based collaborative design method for designing customized garment of disabled people with scoliosis, In: International Journal of Clothing Science and Technology, 2017, vol. 29, no. 2, pp. 226-237.

[27] Hong Y., Bruniaux P., Zeng X., Liu K., Curteza A., Chen Y. Visual-simulation-based personalized garment block design method for physically disabled people with scoliosis (PDPS), In: Autex Research Journal, 2017, vol. 18, no. 1, pp. 35-45.

[28] Rudolf A., Drstvenšek I., Šauperl O., Brajlih T., Strnad M., Ermenc H. Research and development of functional garments for paraplegics, In: Final report on the performed project activities, Slovenian Ministry of Education, Science and Sport, University of Maribor, Faculty of Mechanical Engineering, 2015.

[29] Fras Zemljič L., Peršin Z., Šauperl O., Rudolf A., Kostić M. Medical textiles based on viscose rayon fabrics coated with chitosan encapsulated iodine: antibacterial and antioxidant properties. In: Textile research journal, 2017, First Published August 13, pp. 1-13.

[30] Ortoinfo. Diseases \& Conditions. Kyphosis (Roundback) of the Spine. Available: [https://orthoinfo.aaos.org/ en/diseases—conditions/kyphosis-roundback-of-the-spine]. 
[31] Cupar A. Development of Classification Methodology of Perceptional Surfaces, Ph. D. Dissertation, University of Maribor, Faculty of Mechanical Engineering, Maribor, Slovenia, 2015.

[32] Makehuman, Open source tool for making 3D characters, Available: http://www.makehuman.org/.

[33] Blender. Blender open data. Available: https://www.blender.org/.

[34] Grasshopper® (GH) Davidson Scott, "Grasshopper." Available: http://www.grasshopper3d.com/.

[35] Rhinoceros (RH) Robert McNeel \& Associates, "Rhino5." Available: http://www.rhino3d.com/.

[36] ISO 8559:1989. Garment Construction and Anthropometric Surveys - Body dimensions, 1989.

[37] System M. Müller \& Sohn: Schnittkonstruktionen für Kleider und Blusen, Deutsche Bekleidungs-Akademie München, pp. 41, München: Rundschau Verlag, 1992.

[38] Optitex. Available: http://www.optitex.com/.

\section{Authors:}

\section{ANDREJA RUDOLF ${ }^{1}$, ZORAN STJEPANOVIČ ${ }^{1}$, ANDREJ CUPAR $^{2}$}

${ }^{1}$ University of Maribor, Faculty of Mechanical Engineering, Institute of Engineering Materials and Design,

Maribor, Slovenia

e-mail: andreja.rudolf@um.si

${ }^{2}$ University of Maribor, Faculty of Mechanical Engineering, Institute of Structures and Design, Maribor, Slovenia e-mail: andrej.cupar@um.si

Corresponding author:

ZORAN STJEPANOVIČ

e-mail: zoran.stjepanovic@um.si

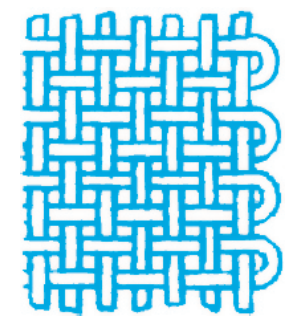

